\title{
DEVELOPMENT OF ANDROID-BASED PROTADROID APPLICATION IN PRONUNCIATION PRACTICE LEARNING FOR UNDERGRADUATE STUDENTS
}

\author{
Ayu Bandu Retnomurti \\ English Education Program, Faculty of Language and Arts, Universitas Indraprasta PGRI, Indonesia \\ E-mail: ayubandu@gmail.com \\ Nurmala Hendrawaty \\ English Education Program, Faculty of Language and Arts, Universitas Indraprasta PGRI, Indonesia \\ E-mail: malahendrawaty@yahoo.com \\ Leni Tiwiyanti \\ English Education Program, Faculty of Language and Arts, Universitas Indraprasta PGRI, Indonesia \\ E-mail: lenitiwiyanti@gmail.com
}

\begin{abstract}
APA Citation: Retnomurti, A. B., Hendrawaty, N., \& Tiwiyanti, L. (2019). Development of Android-based Protadroid application in pronunciation practice learning for undergraduate students. English Review: Journal of English Education, 7(2), 67-76. doi: 10.25134/erjee.v7i2.1721.
\end{abstract}

\begin{abstract}
The research aims at describing the development of PROTADROID, an Android Table Program, to assist learners' pronunciation practice by using non-native English speakers and investigating the affective aspects of using the PROTADROID. The method used was Research and Development (R\&D) which has been chosen to produce a product and test the affective aspects of the product. In order to find out the affective aspect, a questionnaire was applied as an instrument in the data collection. Thirty participants were randomly selected from two Pronunciation Practice classes at Universitas Indraprasta PGRI Jakarta. Based on the development phases, PROTADROID is valid and practical. Further, the four affective aspects indicate that satisfaction is $88.2 \%$ (very satisfied), interest is $93 \%$ (very interested), attention is $76 \%$ (positive), and involvement is $85 \%$ (positive). Hence, it can be concluded that students generally understand and are capable of operating PROTADROID application with high interest.
\end{abstract}

Keywords: affective aspects; Android; pronunciation practice learning; PROTADROID application; research and development.

\section{INTRODUCTION}

Pronunciation is not merely about the correct production of individual sounds or words, but researchers and/or lecturers need to see it as an important part of communication that is integrated into classroom activities (Gilakjani, 2012). Thus, it is suggested that lecturers insist their learners monitor their pronunciation practice in and outside the classroom. The suggestion from the research above is applicable in every ELT learning. It is necessary that the suggestion need to be applied in Pronunciation Practice class at Universitas Indraprasta PGRI.

In ELT learning activities, teachers should bear in mind that the main subject is the students. Consequently, teachers should avoid providing too much input to the students because it will affect students' output. However, Liu (2013) claims teachers should be aware that they are also the organizer and implementer in classroom teaching in addition to being a participant. Teachers can provide suggestion and motivation to students, give them knowledge and ways of learning, but they should remember that the main subject of the learning activities are students.

Teachers teaching Pronunciation class are also expected to have the capability to design the effective teaching and learning activities, decide the required materials, assist the students in performing exercises, and be a model on how to pronounce English correctly. In shorts, teachers are required to be competent, professional, upto-date, and well-informed, and they are able to operate any technology-based media due to increasing students' ability to get information (Norahmi, 2018).

Recently, several studies were conducted to examine pronunciation learning strategies. Baker and Haslam (2012), for example, conducted a questionnaire study with first-grade English majors. In their research, Baker and Haslam 
(2012) suggest that the students' answers show the use of cognitive strategies with applied various strategies. Some of the highest use is speaking in the target language, writing transcription, reading words aloud, listening and repeating, taking phonetic drills, and acting out dialogues. The strategies are effective to be applied in Pronunciation classes; yet, there is still a need in the availability of a more up-todate and more effective learning media.

Android as a mobile operating system is becoming more and more popular as it eases human activities. One of them is the ease in communication, study, and business matters (Hanafi \& Samsudin, 2012). The researchers see how Android can be useful in assisting learning by creating an Android-based application as a Pronunciation Practice mobile learning media. The media refers to what brings information between a source (sender) message to the recipients of the message (Defni \& Rahmayuni, 2014). Therefore, the media should be able to provide ease of use, interesting features, and benefits. This corresponds to what is conveyed by Mehdipour and Zerehkafi (2013) that a good learning media ideally have four main factors, namely the relevance, simplicity, interesting features, and benefit.

The use of a mobile phone in a learning activity which is known as mobile learning (Mlearning) will make the learning process more flexible so that students do not have to attend a special place to learn. It means that the learners can learn anywhere and anytime. Mahamad, Ibrahim, and Taib (2010) suggest that the existing evolution happen in a learning paradigm between traditional classroom-based and electronic learning had introduced a new mobilebased learning paradigm known as mobile learning.

M-learning enhances broader learning experiences for students. As mentioned by Kumar, Wotto, and Bélanger (2018), M-learning is a powerful method for engaging learners on their own terms. The use of mobile devices in mobile learning enables students to engage themselves in learning activities based on their own terms. According to Hanafi and Samsudin (2012), the use of an Android smartphone in the process of language learning is expected to increase the students' eagerness in studying languages. Technology provides assistance for educators to stimulate the students in learning materials, giving explanation or pronouncing simulation on a particular word in English.
In the same vein, Yusri, Goodwin, and Mooney (2015) declare that mobile learning is a type of learning in which students are able to access class materials as desired by utilizing any kinds of wireless communication devices, such as a wireless laptop, Personal Digital Assistant, Personal Computer, tablets or mobile phones. All learning activities nowadays are possible to be conducted via mobile learning, especially Android (Ayed, 2015).

Based on the explanation above, development and innovation in Android-based learning media are expected to adjust language learners' needs and conditions so that the learning process is more qualified based on the demand of the curriculum applied. Learning process in Pronunciation Practice which formerly used a paper-based test in testing the pronunciation accuracy is expected to be more varied by developing learning materials which use Android application. However, the educators' role is important in the learning process.

Learning materials are presented in an interesting form in order to increase the learners' motivation (affective side) and the Androidbased learning can eventually be implemented as a supporting media for learners to understand teaching materials (cognitive side) of the Pronunciation Practice (Harding, 2017). Therefore, the increasing number of students with Android-based mobile devices motivates the writer to develop Android-based teaching materials. Considering this condition, the proposed solution is on the use of a variety of learning media during Pronunciation Practice learning process to create a comfortable learning environment that makes learners more active and become involved in receiving new knowledge. Here, students will eventually use the vocabularies they got to communicate with other people.

The research conducted is a development from the previous web-based PROTATIK in www.protatik.com which is still active until now. The researchers decided to develop a pronunciation practice learning application designed on Android platform. The development is taken due to the easiness and effectiveness of the Android-based application. The PROTADROID application is now already available in Playstore as it has been registered for its Intellectual Property Rights.

Thus, there are two research objectives in this research. The first research objective is to find out whether or not PROTADROID is valid to be 
ENGLISH REVIEW: Journal of English Education Volume 7, Issue 2, June 2019

applied in Pronunciation Practice class. Then, the other objective is to know the affective aspect that the students have in using the application.

\section{METHOD}

This research applied Research and Development approach which was used to produce a product and test the affectivity of the product that has been developed. The research design of the media developed was adapted from step written by Bhawna and Gobind (2015) that includes finding potential and problems, needs analysis, product design, design validation, and product testing. The research was only limited to the product trial stage.

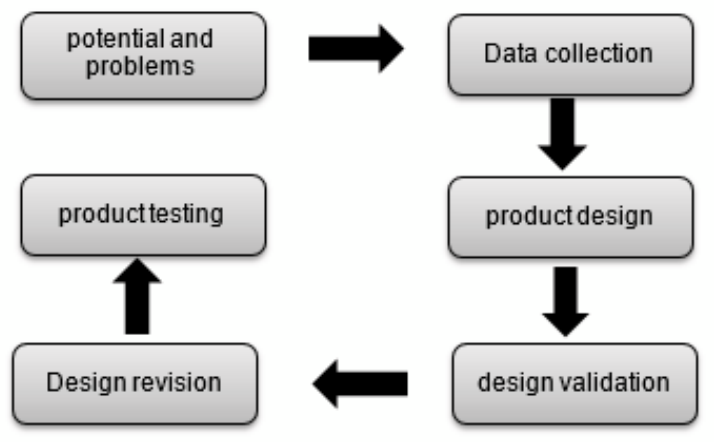

Figure 1. Research design

In order to reach the objective of the research, thirty participants from two classes, R2A and R2B at Universitas Indraprasta PGRI Jakarta were involved. The two classes, which consist of thirty students in total, belong to one of the researcher members. The decision was made in consideration of the practicability and effectiveness for the researchers to monitor the class progress. The students are in their third semester and Pronunciation Practice is one of the classes offered in the semester. The research instruments used in the research were questionnaires, smartphones, and modems. Smartphones and modems are needed as the application is an Android-based one and it requires an internet connection.

Relevant and accurate data is necessary to conduct this research. Data collection techniques were conducted in several ways, namely literature study, student questionnaire sheet, and observation. The researchers decided to use a questionnaire to find out the affective aspects of applying PROTADROID in the Pronunciation Practice class. The questionnaire is considered to be practical compared to interviews. The questionnaires are adapted from Qasim (2011),
p-ISSN 2301-7554, e-ISSN 2541-3643

https://journal.uniku.ac.id/index.php/ERJEE

and the measurement scale used in questionnaires is the Likert scale from 1 to 4 with the indicator aspects as follows:

Table 1. Indicator of instrument

\begin{tabular}{cc}
\hline Indicator & Number of Question \\
\hline Satisfaction & $1-5$ \\
Interest & $6-10$ \\
Attention & $11-15$ \\
Involvement & $16-20$ \\
\hline
\end{tabular}

Before collecting the data, a reliability and validity test were conducted to see whether the items of the questionnaire are reliable and valid or not. The reliability test is done by using the Cronbach's Alpha because the questionnaire employs a Likert scale. From the test, it is known that the instrument has a high reliability as $\mathrm{r}=0,78,0,60<\mathrm{r}<0,80$ (Keyvanfar, et al., 2014). The result of the validity test from 20 items is all valid with $r>0,361$.

Data analysis technique is used to analyze students' questionnaires to represent the affective aspects of using the PROTADROID application during the Pronunciation Practice learning. The quantitative data from the questionnaires will then be converted into qualitative data by using the scale of four. The scoring in single digits is started from 1 up to 4 will then be converted into qualitative data with the following description: very positive, positive, quite positive and not positive. Afterward, in determining the categories of the responses, the researchers adjust the percentage result with the positive criteria (Qasim, 2011) in the following table.

Table 2. Guidelines for response

\begin{tabular}{ll}
\hline \multicolumn{1}{c}{ Percentage } & \multicolumn{1}{c}{ Criteria } \\
\hline $85 \% \leq$ response & very positive \\
$70 \% \leq$ response $<85 \%$ response & positive \\
$50 \% \leq$ response $<70 \%$ response & quite positive \\
$50 \% \leq$ response & not positive \\
\hline
\end{tabular}

\section{RESULTS AND DISCUSSION}

\section{The development of PROTADROID}

PROTADROID is created by using some software such as Android studio 2 for the newest version of IDE (Integrated Development Environment) which can be used to develop an Android application, and Microsoft Word is used as an application to change or repair the material contents in PROTADROID. In addition, edit file menu is used in the making of icon or symbol for the application without any other applications. 
The name of the learning media application is based on the abbreviation of the application content, "PROTADROID" or Program Tabel Android.
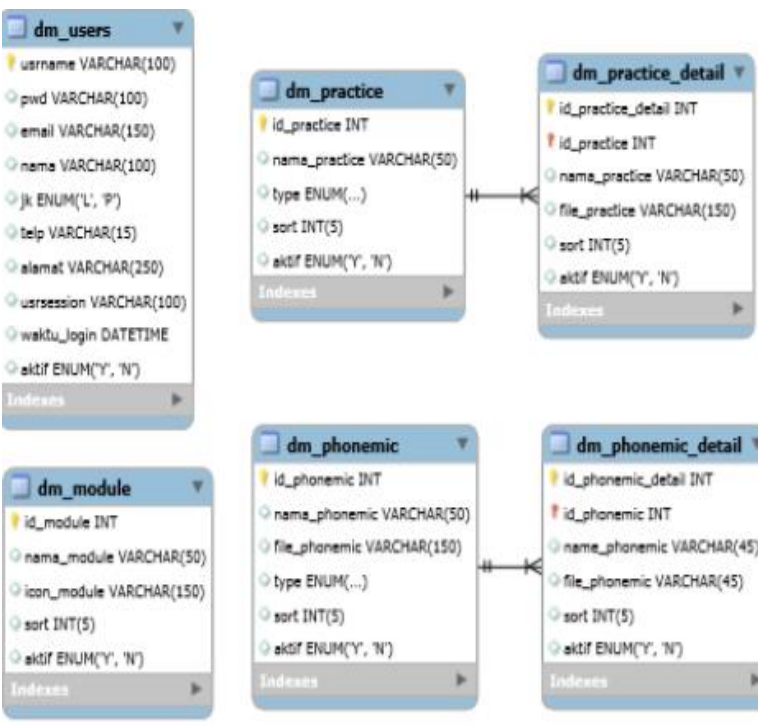

Figure 2. Entity relationship diagram

Figure 2 is the Entity Relationship Diagram (ERD). ERD functions as a valid and practical to use storage for PROTADROID data and design store. There are two contributing factors to application adoption, namely validity and practicality. It is valid as the application is userfriendly and able to operate on Android basis. Users only need to open and $\log$ in to the application. Once they have logged in, they do not need to search the sound on google. It is practical as it is very simple and easy to operate.

The material presented is equipped with the icon and each practice will produce sound by non-native speakers who have been selected based on the appropriateness in pronouncing the materials in the PROTADROID application. In this application, the sound recording of spoken voice from the non-native speakers is inserted to fill the key icon provided in the application. The sound recording is a record of spoken voice which is taken from two pronunciation models who are also lecturers of English Education Program. The two models have passed the preliminary selection. Next, the recording on the spoken voice file is managed by using Windows Media Player from Microsoft. After the recording was set, the voice file was transferred and saved in WAV format and MP3. Next, the team edited the recorded voice to adjust the volume and/or some other important elements of voice and any noises are eliminated from the recording. The voice file which has been edited was then linked to a PHP file and completed with commands. After every single sound file has been connected to each page, the following process is implementing some tests and continued by checking all the available pages.

The aforementioned processes are taken in order to check the coherence between the command and the intended results. The trials are necessary because the test showed that there were several commands that did not work or meet the desired final result. When the file had already been through some examinations, the team conducted some measures to repair the application.

The researchers and some Pronunciation Practice lecturers made an agreement to use nonnative speakers' voice from two lectures. The lecturers chosen are basically colleagues who have passed some selection tests. The decision to use non-native speakers in the exercises is taken in order to meet the teaching target in the Pronunciation Practice class. One of the main reasons in taking the decision is that native speakers who are commonly monolingual are not adaptable enough in imitating accurate features of different languages (Harding, 2017). Harding (2017) sees that non-native speakers generally speak more carefully and regularly compared to native speakers. Such characteristic is a tendency of someone who uses a second or third language. On the other hand, native speakers are considered to speak fast, so students frequently have difficulties to repeat or imitate. Native speakers are also known in using slang, jokes or other specific reference based on their own culture. Typically, non-native-speakers use a limited and easier vocabulary and phrases because they rarely use any figurative languages or slangs. As a result, they understand each other by some facial gestures (Harding, 2017).

The application can easily be downloaded by sharing via Bluetooth among smartphones. The researchers use Google Play facility based on the research policy. The size of the application is approximately 5.11 MB. Although the application is created in the Android platform, this PROTADROID application is meant for the smartphone with Android system version 8 in maximum. The application is now already available in Play Store as it has been registered for its Intellectual Property Rights. Since the application is programmed in an Android-based system, the users can access it anywhere and anytime for learning and teaching interaction, 
and it also has been developed based on Semester Learning Plan in English Education Program, Universitas Indraprasta PGRI.

Referring to the advantages of the PROTADROID application previously mentioned, the application is intended to give a new breakthrough in Pronunciation Practice learning media in English Education Program, Universitas Indraprasta PGRI, Jakarta. Therefore, the lecturers are no longer troubled with the need to provide a tape-recorder, a sound system or move to the language laboratory to use the computers. Moreover, students' references are not limited only on paper-based sources in order to attain Received Pronunciation. Just by installing the application to their mobile phones, they can instantly use the PROTADROID application. The displays of PROTADROID application are shown in Figure 3-8.

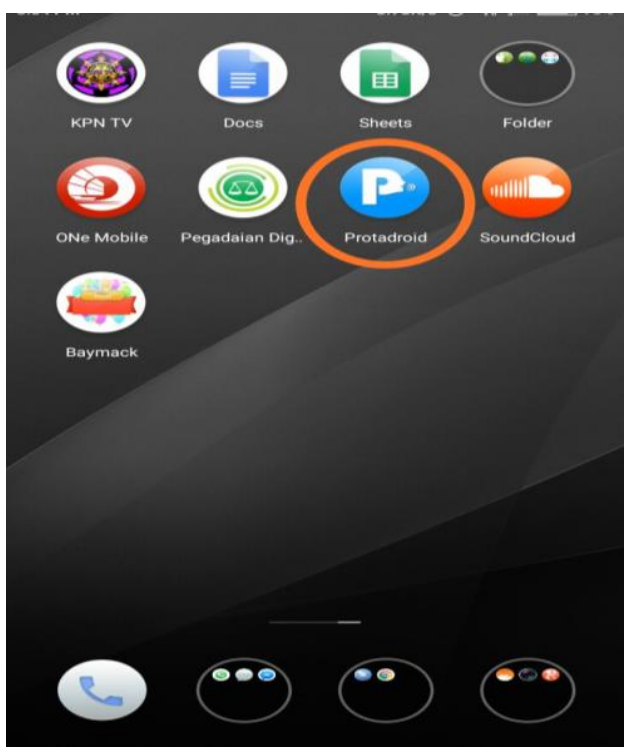

Figure 3. PROTADROID application logo

Figure 3 shows the logo of PROTADROID. The researchers use the letter ' $\mathrm{P}$ ' to represent 'Pronunciation' as the application is focused on providing Pronunciation Practice.

After a user has installed the application, the user is required to fill in username and password. The user can only access the application after they are given permission by the researchers. Figure 4 shows the login page of PROTADROID application. Then, Figure 5 is the display once a user enters the correct username and password. The page gives some motivating remark for pronunciation practice learners and also the names of the developers.

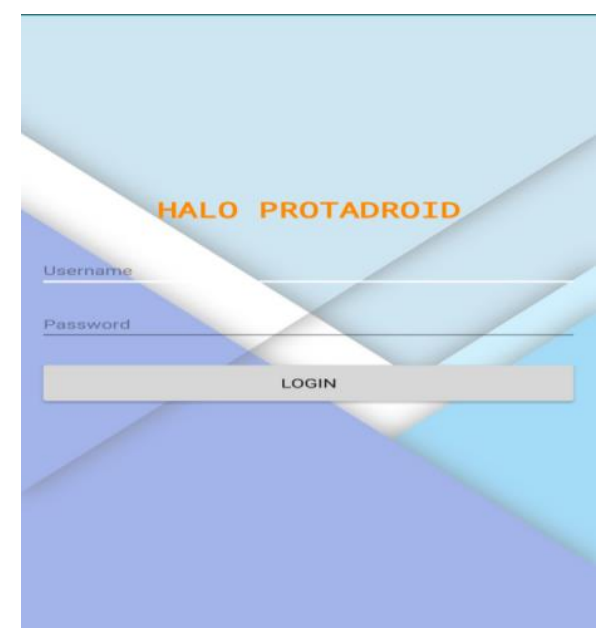

Figure 4. The login page of PROTADROID

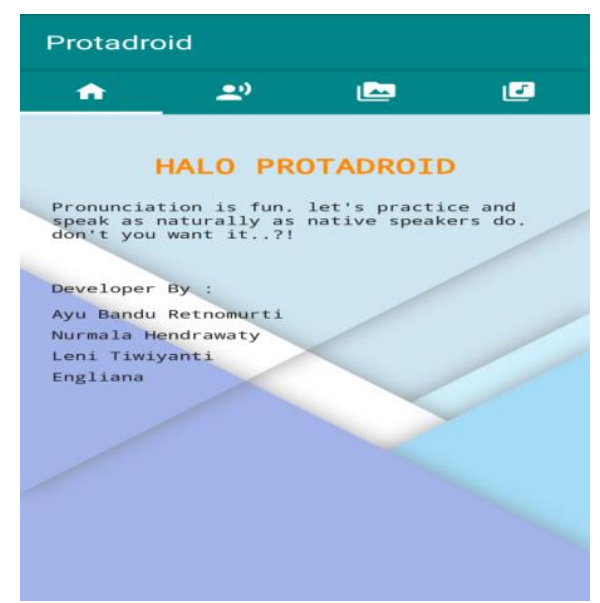

Figure 5. The initial look-up page of PROTADROID

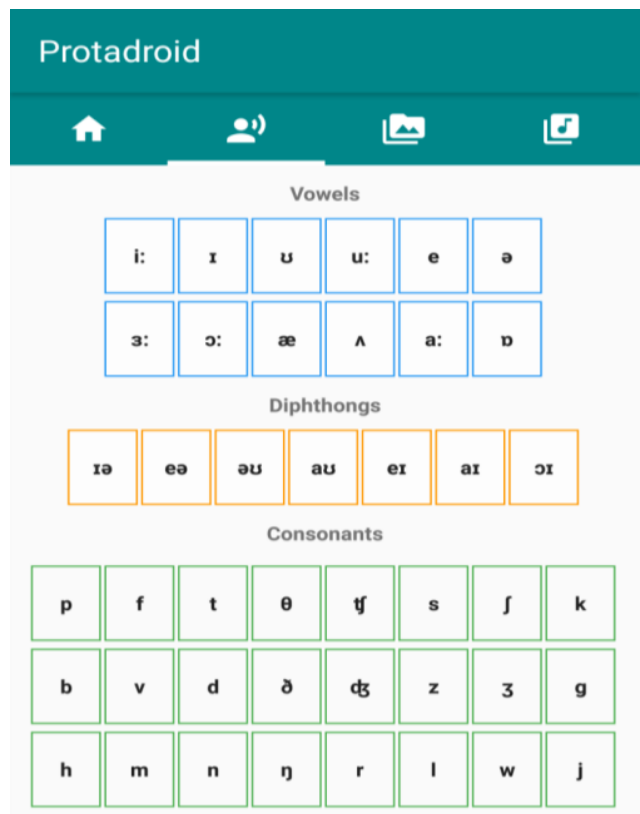

Figure 6. The first materials: vowels, diphthongs, consonant sounds, and examples 
As shown in Figure 6, users are presented with the Pronunciation Practice materials. The first materials of PROTADROID are vowels consisted of diphthongs and consonant sounds with some relevant examples. Users can try each sound by selecting the desired sound to hear the non-native speaker's voice. Users will find the correct pronunciation of each sound with added examples on how the sound is used in words.

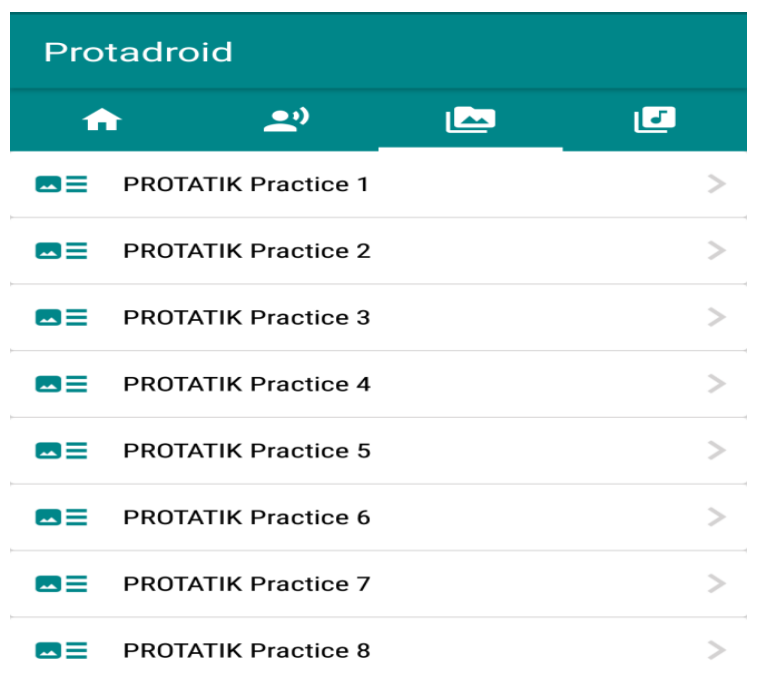

Figure 7. The second materials: pronunciation practice in exercises and examples

In Figure 7, the PROTADROID provides exercises on how each sound is used. The materials are taken from the first year PROTATIK supplement which was published and was ISBN registered. Users will hear how the sounds are pronounced in words, phrases, clauses, or sentences.

\begin{tabular}{|c|c|c|c|}
\hline \multicolumn{4}{|c|}{ Protadroid } \\
\hline \multicolumn{2}{|c|}{$n$} & $\underline{\underline{n}}$ & 5 \\
\hline$\equiv \boldsymbol{\Gamma}$ & Song Lyric Practice 1 & & $>$ \\
\hline$\equiv \boldsymbol{J}$ & Song Lyric Practice 2 & & $>$ \\
\hline$\equiv \boldsymbol{J}$ & Song Lyric Practice 3 & & $>$ \\
\hline$\equiv \boldsymbol{J}$ & Song Lyric Practice 4 & & $>$ \\
\hline$\equiv \boldsymbol{J}$ & Song Lyric Practice 5 & & $>$ \\
\hline$\equiv \boldsymbol{\Sigma}$ & Song Lyric Practice 6 & & $>$ \\
\hline$\equiv \boldsymbol{J}$ & Song Lyric Practice 7 & & $>$ \\
\hline$\equiv \boldsymbol{J}$ & Song Lyric Practice 8 & & $>$ \\
\hline
\end{tabular}

Figure 8. The third material: exercises of pronunciation by using song lyrics
In Figure 8, PROTADROID gives a collection of exercises taken from songs. From the song lyrics, students are expected to be able to listen and answer the exercises to practice their skills in listening and pronouncing the song lyrics. While listening to the songs, the students should refer to the PROTADROID Supplement which is still in the publication process and has not been ISBN registered.

The final product of PROTADROID has passed the validation process phase, revision and field test by experts from both a doctor in Information Technology (as technology expert) and a doctor in English language (as material expert). The result of the validation process phase is shown in Table 3 and Table 4.

Table 3. PROTADROID evaluation by

\begin{tabular}{|c|c|c|c|c|c|}
\hline \multirow{4}{*}{ No } & \multicolumn{5}{|c|}{ technology expert } \\
\hline & \multirow{3}{*}{$\begin{array}{l}\text { PROTADROID } \\
\text { Application } \\
\text { Evaluation }\end{array}$} & \multirow{2}{*}{\multicolumn{4}{|c|}{$\begin{array}{c}\text { PROTADROID Evaluation } \\
\text { Evaluation RESULT }\end{array}$}} \\
\hline & & & & & \\
\hline & & Inadeq & Adeq & Go & Exce \\
\hline 1. & $\begin{array}{l}\text { Aspect of } \\
\text { PROTADROID } \\
\text { content }\end{array}$ & & & $\sqrt{ }$ & \\
\hline 2. & $\begin{array}{l}\text { Aspect of the non- } \\
\text { native speakers' } \\
\text { voice }\end{array}$ & & & $\sqrt{ }$ & \\
\hline 3. & $\begin{array}{l}\text { Aspect of } \\
\text { PROTADROID } \\
\text { design }\end{array}$ & & & $\sqrt{ }$ & \\
\hline 4. & $\begin{array}{l}\text { Aspect of } \\
\text { PROTADROID lay } \\
\text { out }\end{array}$ & & & $\sqrt{ }$ & \\
\hline 5. & $\begin{array}{l}\text { Aspect of } \\
\text { PROTADROID } \\
\text { display template }\end{array}$ & & & $\sqrt{ }$ & \\
\hline 6. & $\begin{array}{l}\text { Aspect of } \\
\text { PROTADROID } \\
\text { Image design }\end{array}$ & & & $\sqrt{ }$ & \\
\hline 7. & $\begin{array}{l}\text { Aspect of } \\
\text { PROTADROID } \\
\text { colours }\end{array}$ & & $\sqrt{ }$ & & \\
\hline 8. & $\begin{array}{l}\text { The aspect of the } \\
\text { brand name of } \\
\text { PROTADROID } \\
\text { product }\end{array}$ & & & & $\sqrt{ }$ \\
\hline
\end{tabular}

In Table 3, the validation consisted of eight aspects. The PORTADROID application was considered good on content, the non-native speaker voice, design, layout, display template and design. The application was adequate in terms of colors and excellent in the choice of brand name. The technology expert saw that the content was considered to be complete and understandable for users. The non-native speakers' voice was also considered clear and understandable. The design, layout and display template also met the ideal setting that they 
managed to cover all phonetic transcriptions along with the exercises provided.

The expert highly appreciated the choice for the brand name for its uniqueness and would easily remind the users about the objective and the content of the application. The Brand name was taken from the concept of Android as its application base and pronunciation as its main content. It was easy to pronounce, spell and remember. There were a few revisions given by the technology expert, such as: 1) some of the non-native speakers' voice recording should be made louder and 2) the color should be made brighter. The expert suggested using a color variation.

Table 4. PROTADROID evaluation by material

\begin{tabular}{|c|c|c|c|c|c|}
\hline \multicolumn{6}{|c|}{ expert } \\
\hline \multirow[t]{2}{*}{ No } & \multirow{2}{*}{$\begin{array}{l}\text { PROTADROID } \\
\text { Application } \\
\text { Evaluation }\end{array}$} & \multicolumn{4}{|c|}{$\begin{array}{l}\text { PROTADROID Evaluation } \\
\text { Evaluation RESULT }\end{array}$} \\
\hline & & $\begin{array}{l}\text { Inadeq } \\
\text { uate }\end{array}$ & $\begin{array}{l}\text { Adeq } \\
\text { uate }\end{array}$ & $\begin{array}{l}\text { Go } \\
\text { od }\end{array}$ & $\begin{array}{l}\text { Exce } \\
\text { llent }\end{array}$ \\
\hline 1. & $\begin{array}{l}\text { In terms of } \\
\text { PROTADROID } \\
\text { content }\end{array}$ & & & $\sqrt{ }$ & \\
\hline 2. & $\begin{array}{l}\text { In terms of quality } \\
\text { of the non-native } \\
\text { speakers }\end{array}$ & & & $\sqrt{ }$ & \\
\hline 3. & $\begin{array}{l}\text { In terms of } \\
\text { PROTADROID } \\
\text { exercise material }\end{array}$ & & $\sqrt{ }$ & & \\
\hline 4. & $\begin{array}{l}\text { In terms of } \\
\text { PROTADROID } \\
\text { material choice }\end{array}$ & & & & $\sqrt{ }$ \\
\hline
\end{tabular}

Table 4 shows the result of another examination conducted by an English language expert. She evaluated the material content, the quality of the non-native speakers, the exercise material and the material choice in the PROTADROID application. The results of the evaluation stated that the material content and the quality of the non-native speakers were good, the exercise materials were adequate and the material choices were excellent.

The material content was suitable with the supplement book that had already been designed and the quality of the non-native speakers was good as the speakers could give the correct pronunciation of the phonetic symbols. The use of the non-native speakers was an improvement that the material expert saw to be the selling point of the PROTADROID application. Furthermore, the material choice was excellent as the PROTADROID application covered all the phonetic symbols into its content.

In addition, the material expert also gave some recommendations for the research team. As a material expert, there was a need for the research team to give more examples and exercises. So far, there were only three examples of the use of each phonetic symbols. Some more examples would make a deeper understanding of the learners.

Based on both evaluation provided by the technology and the material experts, the Android-based PROTADROID development was then confirmed to be valid. It brings advantages to enhance the quality of the students' achievement in Pronunciation Practice learning. The instructional media generated has a number of advantages, including and foremost is on its function as a mobile learning media which runs on the Android smartphone that makes the learning media easier to access anywhere and anytime. This application is also practical. Based on the conducted research, PROTADROID is valid since it has been examined based on expert judgments.

There are some advantages that the users find in using the application. Firstly, this application is practical because it is handy and convenient. The application is accessible to users anytime and anywhere. Secondly, the application is enjoyable as it provides some songs that they are familiar with. Last but not least, it is easily comprehensible as the voice is from two competent non-native speakers.

After some revision made by the research team and in order to enable the students to use the application, the PROTADROID application was published in Play Store. In doing so, the research team could distribute the application to the participants to conduct the next reseach focusing on the affective aspect on applying PROTRADOID aplication in Pronunciation Practice Classes. Users can download by searching the application name, PROTADROID, in the Play Store as shown in Figure 9.

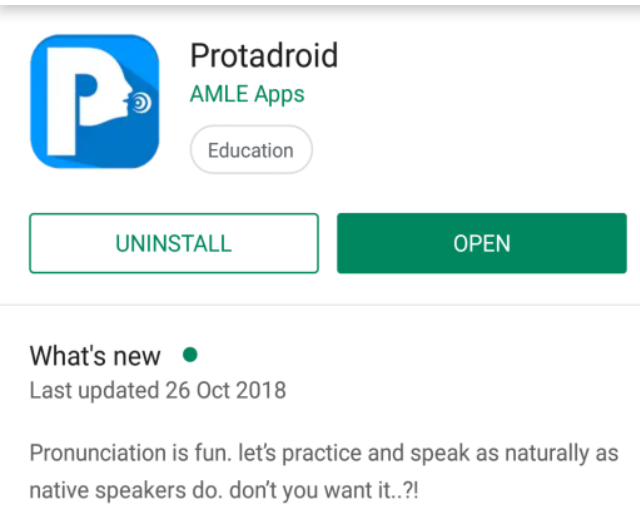

Figure 9. PROTADROID in Google Play Store 


\section{Affective aspect of PROTADROID}

Affective aspect refers to the emotional or feeling segment of an attitude that is brought to the surface about something. It deals with impulse, desire, and striving. Meanwhile, the cognitive aspect is related to the mental process to acquire knowledge by using the existing beliefs, thoughts, and attributes that are associated with an object (Thibault, et al., 2014). As stated by Qasim (2011), there are four affective aspects; satisfaction, interest, attention, and involvement. The four affective aspects then become indicators in the research questionnaire in which each indicator has five questions.

In order to identify the affective aspects of the Pronunciation Practice, the research team decided to use a questionnaire. It described the students' satisfaction, interest, attention, and involvement. The questions were well chosen to meet the research objectives. Next, the result obtained from the questionnaire was analyzed by using the following formula (Yin, 2017).

$$
P=\frac{f}{N} \times 100 \%
$$

Details:

$\mathrm{P}=$ Percentage

$\mathrm{F}=$ Frequency aimed or obtained scores

$\mathrm{N}=$ Number of cases or maximum score

The results of the percentage of each indicator were depicted in Table 5.

Table 5. The percentage of students' affective

\begin{tabular}{ccc}
\multicolumn{3}{c}{ aspects } \\
\hline No & Aspects & Percentage \\
\hline 1. & Satisfaction & $88.2 \%$ \\
2. & Interest & $93 \%$ \\
3. & Attention & $76 \%$ \\
4. & Involvement & $85 \%$ \\
\hline
\end{tabular}

Number of cases or maximum score $(\mathrm{N})=1250$

Obtained score of satisfaction $=1103$

$\mathrm{P}=1103 / 1250 \times 100 \%=88,2 \%$

Obtained score of interest $=1163$

$\mathrm{P}=1163 / 1250 \times 100 \%=93 \%$

Obtained score of attention $=950$

$\mathrm{P}=950 / 1250 \times 100 \%=76 \%$

Obtained score of involvement $=1063$

$\mathrm{P}=1063 / 1250 \times 100 \%=85 \%$

Afterward, in determining the categories of students' responses, the researchers adjusted the percentage result with the positive criteria stated by Qasim (2011) as presented in Table 6. Meanwhile, Table 7 shows the final result of students' affective aspects in using PROTADROID application.

Table 6. Guidelines for the positive criteria

\begin{tabular}{ll}
\hline \multicolumn{1}{c}{ Percentage } & \multicolumn{1}{c}{ Positive } \\
\hline $85 \% \leq$ response & $=$ very positive \\
$70 \% \leq$ response $<85 \%$ & $=$ positive \\
$50 \% \leq$ response $<70 \%$ & $=$ quite positive \\
$50 \% \leq$ response & $=$ not positive \\
\hline
\end{tabular}

Table 7. Percentage and positive criteria of

\begin{tabular}{llll} 
& \multicolumn{2}{c}{ students' affective aspects } \\
\hline No & Aspects & Percentage & Categories \\
\hline 1 & Satisfaction & $88.2 \%$ & $\begin{array}{l}\text { Very } \\
\text { satisfied }\end{array}$ \\
2 & Interest & $93 \%$ & $\begin{array}{l}\text { Very } \\
\text { interested }\end{array}$ \\
3 & Attention & $76 \%$ & $\begin{array}{l}\text { Positive } \\
\text { Positive }\end{array}$ \\
\hline
\end{tabular}

Table 7 shows that out of thirty participants, the percentage of satisfaction was $88.2 \%$ with very satisfied category, interest was $93 \%$ with very interested category, attention was $76 \%$ with positive category, and involvement was $85 \%$ with positive category. The highest aspect was interest followed by satisfaction, involvement, and the lowest one was attention.

The result has shown that the students' interest in learning Pronunciation Practice by using PROTADROID is very high. It means that the students are actively and independently involved in the teaching process. Moreover, satisfaction and interest in using the application can increase the students' desire in studying.

In terms of all of the four affective aspects examined, the materials included in PROTADROID application are interesting for students. The materials chosen increased the students motivation (affective aspect). Consequently, the Android-based learning media is considered applicable to be used as a learning media to comprehend learning materials (cognitive aspect) in Pronunciation Practice classes.

\section{CONCLUSION}

On the basis of results and discussion, PROTADROID is valid and practical. All appropriateness aspects observed which include language, media, and material aspects have been fulfilled. The application helps lecturer and students in engaging themselves in learning and practicing Pronunciation Practice materials on their own terms. Besides, the application is very pleasurable as it gives relaxing and interesting 
learning activities. By including English songs in the application, students can actively practice the use of the correct English pronunciation in singing songs.

Based on the questionnaire given to the students, there is a positive attitude towards the PROTADROID application. Out of the four affective aspects employed by thirty participants, the highest aspect is on interest followed by satisfaction, involvement, and the lowest one is attention aspect. It is evidence that the students' interest in learning Pronunciation Practice by using PROTADROID is very high.

\section{ACKNOWLEDGEMENT}

The researchers would like to convey their first gratitude to the Directorate of Research and Development, Ministry of Research, Technology and Higher Education, and also Kopertis Regional III Jakarta as the financial support of the publication. The next gratitude goes to the programmer team, CV Afiata Solusindo Sejahtera. Finally, the researcher team would like to express their gratitude to all parties involved in the research.

\section{REFERENCES}

Ayed, A. B. (2015). A literature review on Android permission system. International Journal of Advanced Research in Computer Engineering \& Technology (IJARCET), 4(4).

Baker, S. W., \& Haslam, N. (2012). The effect of language learning aptitude, strategy use and learning context on L2 pronunciation learning. Applied Linguistics, 34(4), 435-456.

Bhawna, \& Gobind. (2015). Research methodology and approaches. IOSR Journal of Research \& Method in Education Ver, 5(3), 2320-7388. doi: 10.9790/7388-05344851.

Defni, D., \& Rahmayuni, I. (2014). Enkripsi SMS (Short Message Service) pada telepon selular berbasis Android dengan metode RC6. Jurnal Momentum, 16(1).

Gilakjani, A. P. (2012). The significance of pronunciation in English language teaching. English Language Teaching. doi: 10.5539/elt.v5n4p96.

Hanafi, H. F., \& Samsudin, K. (2012). Mobile learning environment system (MLES): The case of Android-based learning application on undergraduates' learning. arXiv preprint arXiv:1204.1839.

Harding, L. (2017). Validity in pronunciation assessment. In Assessment in second language pronunciation (pp. 42-60). London: Routledge.

Keyvanfar, A., Shafaghat, A., Majid, M. A., Lamit, H., \& Ali, K. N. (2014). Correlation study on user satisfaction from adaptive behavior and energy consumption in office buildings. Jurnal Teknologi, 70(7), 89-97.

Kumar, B. S., Wotto, M., \& Bélanger, P. (2018). Elearning, m-learning and d-learning: Conceptual definition and comparative analysis. E-Learning and Digital Media, 15, 191-216. doi: $10.1177 / 2042753018785180$.

Liu, W. (2013). Role of teachers in oral English teaching. Proceedings of the International Conference on Information Engineering and Applications (IEA) 2012 (pp. 13-18). New York: Springer.

Mahamad, S., Ibrahim, M. N., \& Taib, S. M. (2010). M-learning: A new paradigm of learning mathematics in Malaysia. arXiv preprint arXiv:1009.1170.

Mehdipour, Y., \& Zerehkafi, H. (2013). Mobile learning for education: Benefits and challenges. International Journal of Computational Engineering Research, 3(6), 93-101.

Norahmi, M. (2018). 21st-century teachers: The students' perspectives. Journal on English as a Foreign Language. doi: 10.23971/jefl.v7i1.538.

Qasim, S. (2011). How to do your research project. International Journal of Research \& Method in Education. doi: 10.1080/1743727x.2011.573272.

Thibault, K., Fan, M., Snollaerts, T., Smith, G. M., Rancillac, A., Sordoillet, V., ... Lin, W. K. (2014). BDNF-Dependent plasticity induced by peripheral inflammation in the primary sensory and the cingulate cortex triggers cold allodynia and reveals a major role for endogenous BDNF as a tuner of the affective aspect of pain. Journal of Neuroscience. doi: 10.1523/jneurosci.086014.2014.

Yin, R. K. (2017). Case study research and applications: Design and methods. London: Sage Publications. doi: 10.1016/j.jada.2010.09.005.

Yusri, I. K., Goodwin, R., \& Mooney, C. (2015). Teachers and mobile learning perception: Towards a conceptual model of mobile learning for training. Procedia - Social and Behavioral Sciences, $176, \quad 425-430 . \quad$ doi: 10.1016/j.sbspro.2015.01.492. 
Ayu Bandu Retnomurti, Nurmala Hendrawaty, \& Leni Tiwiyanti

Development of Android-based Protadroid application in pronunciation practice learning for undergraduate students 